\title{
Menumbuhkan Sikap Empati Siswa Dengan Menggunakan Metode Role Model Dalam Pembelajaran IPS ( Penelitian Tindakan Kelas di SMP 44 Bandung di Kelas VII A)
}

\author{
Alifha Nurfidia \\ Prodi Pendidikan Ilmu Pengetahuan Sosial \\ Fakultas Pendidikan Ilmu Pengetahuan Sosial \\ Universitas Pendidikan Indonesia \\ Alifha.nurfidia@yahoo.com
}

\begin{abstract}
ABSTRAK
Penelitian ini dilatar belakangi oleh permasalahan yang ditemukan peneliti pada saat melakukan observasi awal yaitu rendahnya sikap empati siswa dalam pembelajaran IPS. Hal ini ditunjukan dengan beberapa indikasi diantaranya . Pertama, kurangnya tolong-menolong pada saat teman membutuhkan bantuan. Kedua, pada saat kegiatan belajar mengajar peserta didik kurang dalam memperhatikan guru dan teman yang sedang berbicaraterkait pelajaran. Ketiga, pada saat kegiatan belajar mengajar siswa terlihat melakukan bullying terhadap teman yang cenderung pendiam di kelas. Keempat, sikap siswa yang membedabedakan teman berdasarkan status sosial dan fisik ini terlihat dari posisi tempat duduk dan interaksi siswa Kelima, sikap ketidak pedulian siswa dengan teman sekelas. Alternatif pemecahan masalah tersebut dilakukan dengan cara menggunakan metode pembelajaran role model. Meninjau permasalahan yang akan diteliti berkaitan dengan proses pembelajaran, maka peneliti memilih Penelitian Tindakan Kelas (PTK) dengan model Kemmis Mc. Teggart yang dilakukan dalam 3 siklus.
\end{abstract}

Kata Kunci: Sikap Empati, Metode Pembelajaran Role Model, PembelajaranIPS. 


\title{
ABSTRACK \\ Cultivate the attitude Empathy Students Method Using Role Model In the Learning IPS \\ (Class Action Research in SMP 44 Bandung in Class VII A)
}

\begin{abstract}
This research is motivated by the problems found researchers at the time of the initial observation as the low empathy of students in IPS. This is evidenced by some indications of them. First, the lack of mutual help when a friend needs help. Second, at the time of teaching and learning activities of students lacking in attention to teachers and friends who are berbicaraterkait lesson. Thirdly, during the learning activities of students seen bullying behavior toward friends who tend to be quiet in class. Fourth, the students' attitudes discriminating friend based social and physical status is visible from the seating position and student interaction Fifth, the attitude of indifference students with classmates. Alternative solutions is done by using the method of learning a role model. Reviewing the problems to be studied with regard to the learning process, the researchers chose a Class Action Research (CAR) model Kemmis Mc. Teggart performed in three cycles.
\end{abstract}

Keywords: Attitudes Empathy, Learning Method Role Model, Learning IPS 


\section{A. Latar Belakang}

Pendidikan pada dasarnya merupakan bagian integral dalam proses pembangunan. Berbicara tentang proses pendidikan sudah tentu tidak dapat dipisahkan dengan semua upaya yang harus dilakukan untuk mengembangkan sumber daya yang berkualitas sebagai modal dasar pembangunan. Hal ini selaras dengan pengertian pendidikan menurut UU No. 20 tahun 2003 tentang sistem Pendidikan Nasional, "pendidikan adalah usaha sadar dan terencana untuk mewujudkan suasana belajar dan proses pembelajaran agar peserta didik secara aktif mengembangkan potensi dirinya untuk memiliki kekuatan spiritual keagamaan, pengendalian diri, kepribadian, kecerdasan, akhlak mulia serta keterampilan yang diperlukan dirinya, masyarakat, bangsa dan negara (Somarya dan Pupun, 2010:26).

Tujuan pendidikan nasional dalam UU No. 20 Tahun 2003, yaitu : Sistem pendidikan nasional berfungsi untuk mengembangkan kemampuan dan untuk membentuk watak serta peradaban bangsa yang bermanfaat dalam rangka mencerdaskan kehidupan bangsa, bertujuan untuk berkembangnya potensi peserta didik agar menjadi manusia yang beriman dan bertaqwa pada Tuhan Yang Esa, berakhlak mulia, sehat, berilmu, cakap, kreatif, mandiri, dan menjadi warga negara yang baik dan demokratis serta bertanggung jawab(Ruhimat,2009:20)".

Berdasarkan dasar pemikiran tersebut, peneliti dapat memahami bahwa pendidikan dapat dimaknai sebagai proses tidak hanya mencakup pengembangan intelektual saja, akan tetapi lebih ditekankan pada proses pembinaan kepribadian atau karakter peserta didik secara menyeluruh. Oleh karena itu, pendidikan merupakan salah satu faktor penentu kemajuan bangsa dan negara. Selain itu, peneliti juga dapat memahami bahwa melalui proses pendidikan secara tidak langsung dapat menunjang proses mengubah tingkah laku peserta didik agar mampu hidup mandiri dalam lingkungan alam sekitar.

Dari kajian di atas dapat dipahami bahwa pendidikan sangat berperan penting dalam membangun karakter bangsa. Hal tersebut telah terangkum dalam pendidikan karakter yang mengandung 18 nilai-nilai karakter yang ditetapkan secara tertulis oleh Kemendiknas pada tahun 2011. 
Karakter tersebut antara lain religius, jujur, toleransi, disiplin, kerja keras, kreatif, mandiri demokrasi, rasa ingin tahu, semangat kebangsaan, atau nasionalisme, cinta tanah air, menghargai prestasi, komunikatif, cinta damai, gemar membaca, peduli lingkungan, peduli sosial, dan tanggung jawab. Berdasarkan pemaparan nilai-nilai karakter tersebut dalam perundangan, pengembangan karakter nampak sangat jelas menjadi ruh dari pendidikan di Indonesia (Rahayu, 2015:21).

Memahami pemikiran tersebut jelaslah semua mata pelajaran pada berbagai tingkat pendidikan memiliki kewajiban untuk mengembangkan pendidikan karakter termasuk pendidikan IPS. Ilmu Pengetahuan Sosial (IPS) sebagai salah satu mata pelajaran dalam tingkat persekolahan di SMP memiliki berbagai tujuan. Menurut Sumantri (2001:93) bahwa pendidikan IPS adalah “ penyerdehanaan atau adaptasi dari disiplin ilmu-ilmu sosial dan humaniora, serta kegiatan dasar manusia yang diorganisasikan dan dikaji secara ilmiah dan pedagogis atau psikologis untuk tujuan pendidikan”.

Berdasarkan pendapat Sumantri di atas peneliti dapat memahami bahwa IPS merupakan suatu produk mata pelajaran yang sangat menunjang terbentuknya generasi yang peka terhadap lingkungan sosial. Alasan ini didasari oleh IPS yang dihasilkan dari pengintegrasian dan pengorganisasian antara beberapa disiplin ilmu yang meliputi humaniora, sosiologi, geografi, sejarah dan sebagainya. Kemudian hasil integrasi disiplin ilmu tersebut diintegrasikan kembali dengan kondisi sosial masyarakat yang dikaji secara pedagogis dan psikologis untuk disesuaikan dengan kondisi peserta didik dan menunjang pencapaian tujuan pembelajaran serta menunjang terbentuknya kepekaan sosial pada peserta didik. Guna mencapai hal-hal tersebut pada pembelajaran IPS tentunya diperlukan suatu proses yang struktur dan sistematis dalam pembelajaran yang disebut sebagai kurikulum. Dengan adanya kurikulum proses pembelajaran IPS akan lebih optimal terutama dalam mencapai tujuan pembelajaran.

Kajian peneliti di atas selaras dengan pendapat Sapriya (2008 hlm.5) bahwa "Ilmu Pengetahuan Sosial adalah suatu mata pelajaran yang ada di dalam kurikulum persekolahan”. Dari pendapat Sapriya peneliti dapat memahami bahwa IPS merupakan mata pelajaran yang tersusun dalam 
kurikulum persekolahan oleh karena itu dalam pelaksanaannya harus sesuai dengan kaidah kurikulum yang bersifat struktural dan sistematis untuk menunjang tujuan pembelajaran. Dalam kurikulum setiap mata pelajaran termasuk IPS akan selalu berisi muatan pesan nilai, norma, dan prinsip-prinsip moral yang sejalan dengan kebutuhan dan kepentingan peserta didik. Dengan demikian kurikulum dalam pembelajaran IPS sangat menunjang untuk pencapaian tujuan pembelajaran IPS .

Tujuan pembelajaran IPS dalam Permendiknas Nomor 22 tahun 2006, yaitu sebagai berikut:

1. Mengenal konsep-konsep yang berkaitan dengan kehidupan masyarakat dan lingkungannya

2. Memiliki kemampuan dasar berpikir logis dan kritis, rasa ingin tahu, inkuiri, memecahkan masalahdan keterampilan dalan kehidupan sosial

3. Memiliki komitmen dan kesadaran terhadap nilai-nilai sosial dan kemanusiaan

4. Memiliki kemampuan berkomunikasi, bekerjasama dan berkompetisi dalam masyarakat yang majemuk, baik tingkat nasional, maupun global

Berdasarkan penjelasan mengenai hakikat dan tujuan pembelajaran IPS peneliti dapat memahami bahwa melalui proses pembelajaran diharapkan siswa bisa memiliki komitmen dan kesadaran terhadap nilai-nilai sosial dan kemanusiaan termasuk nilai-nilai karakter empati sebagai wujud sikap peka terhadap kehidupan sosial sehingga dapat menjadi warga negara yang baik.

Berdasarkan pemaparan diatas peneliti dapat menarik benang merah bahwa salah satu nilai sosial yang sangat penting bagi siswa sebagai mahluk sosial adalah empati. Hal ini dilatar belakangi oleh kondisi saat ini yang menunjukan kecenderungan kurang tertanamnya sikap empati sosial pada kalangan remaja (siswa SMP). Hal tersebut terbukti dengan beberapa kasus yang menunjukan kurangnya sikap empati. Secara khusus berdasarkan hasil observasi yang telah dilakukan di lapangan, peneliti mendapatkan temuan bahwa terdapat indikasi-indikasi yang menandakan bahwa sikap empati di kelas VII A SMP Negeri 44 Bandung rendah. Indikasi-indikasi tersebut 
diantaranya pertama, kurangnya tolong-menolong pada saat teman membutuhkan bantuan saat kegiatan belajar mengajar hal ini tampak ketika terjadi ketidaksesuaian antara jumlah buku dan jumlah siswa yang mendapatkan buku pelajaran. Saat itu terlihat sebagian siswa yang memperoleh buku tidak berinisiatif untuk berbagi dengan teman yang tidak kebagian buku pelajaran. Kedua, pada saat kegiatan belajar mengajar peserta didik kurang dalam memperhatikan guru dan teman yang sedang berbicaraterkait pelajaran. Ketiga, pada saat kegiatan belajar mengajar siswa terlihat melakukan bullying terhadap teman yang cenderung pendiam di kelas. Keempat, sikap siswa yang membeda-bedakan teman berdasarkan status sosial dan fisik ini terlihat dari posisi tempat duduk dan interaksi siswa. Hal ini terlihat pada bagian barisan depan didominasi oleh siswa yang pintar sedangkan bagian pojok belakang identik dengan siswa pendiam. Kondisi ini menunjukan kurangnya kebersatuan pada siswa kelas VII A. Kelima, sikap ketidak pedulian siswa dengan teman sekelas. Hal ini terlihat ketika ada teman yang tidak hadir sudah lebih empat hari tetapi tidak ada satupun siswa di kelas yang mengetahuinya.

Dari hasil pengamatan tersebut tampak jelas bahwasanya kelas VII-A memiliki kecenderungan rendahnya empati sebagai wujud sikap sosial dan kemanusiaan. Keadaan tersebut dari pandangan teori belajar behavioristik dapat disebabkan oleh minimnya pengalaman siswa dalam kehidupan seharihari (Wilis,2006:96). Dari pendapat Wilis peneliti dapat memahami bahwa pengalaman belajar sangat penting karena dengan berpengalaman belajar secara tidak langsung siswa melibatkan perasaan, pikiran, dan sikap siswa pada suatu lingkungan belajar hingga memperoleh makna. Hal ini sejelan dengan pendapat Bandura "segenap belajar yang diperoleh melalui pengalaman langsung bisa pula diperoleh secara tidak langsung dengan memperhatikan tingkah laku orang lain berikut konsekuensi-konsekuensinya" (Yanti dkk, 2013:2).

Berdasarkan pendapat Bandura peneliti dapat memahami bahwa selain memperoleh makna dalam suatu pengalaman belajar. Siswa juga dapat 
berinteraksi langsung dengan sumber belajar kontekstual. Dalam hal ini siswa dapat berhubungan dengan orang-orang sekitar siswa dalam kehidupan sosial hingga menjadi satu pengalaman belajar.

Kajian peneliti tersebut selaras dengan pendapat Alisyahbana yang menyatakan "sikap sosial seseorang itu akan tampak dalam cara individu bereaksi terhadap orang-orang di sekitarnya dan bagaimana pengaruh hubungan itu terhadap dirinya. Perilaku sosial juga identik dengan reaksi seseorang terhadap orang lain. Perilaku itu ditunjukkan dengan perasaan, tindakan, sikap, keyakinan, kenangan, atau rasa hormat terhadap orang lain termasuk sikap empati” (dalam Ali, 2009:85). Dari pendapat Alisyahbana dapat peneliti pahami bahwa lingkungan merupakan salah satu wadah pengalaman belajar yang dapat memicu terciptanya sikap sosial. Oleh karena itu dalam pembelajaran IPS lingkungan dan dinamika masyarakat merupakan sumber belajar yang utama.

Namun, proses pembelajaran yang belum berbasis lingkungan sekitar mengakibatkan, nilai sikap sosial yang didapat dalam kehidupan sosial bermasyarakat belum seutuhnya dimiliki siswa. Sikap sosial merupakan salah satu aspek non kognitif yang seringkali dilupakan peranannya. Indikasi perilaku sosial yang baik adalah seperti sopan santun, saling tolong-menolong, memberi sedekah, suka bekerjasama, menghormati orang tua, melestarikan lingkungan, tidak memaksakan kehendak kepada orang lain, empati dan bisa diterima masyarakat serta terciptanya keharmonisan hubungan antar sesama. Sebaliknya, orang yang cerdas secara intelektual tidak tahu bagaimana bergaul. Hal ini ditunjukan dengan sikap yang cenderung egois, ingin menang sendiri, tidak menghargai orang lain. Sikap tersebut tentunya tidak akan diterima baik oleh masyarakat dalam pergaulannya.

Guna menunjang tercapainya hasil pembelajaran yang menunjukan karater siswa yang baik seperti empati adalah proses pembelajaran yang ditunjang dengan metode pembelajaran yang relevan. Salah satu model yang dapat digunakan adalah Contextual Teaching and Learning (CTL) sebab menurut Nurhadi (2004:12) CTL merupakan sistem pembelajaran yang cocok dengan 
kinerja otak, untuk menyusun pola-pola yang mewujudkan makna, dengan cara menghubungkan muatan akademis dengan konteks kehidupan sehari-hari peserta didik. Dari pendapat Nurhadi tersebut peneliti dapat memahami bahwa siswa didorong agar menemukan hubungan antara materi yang dipelajari dengan situasi kehidupan nyata, artinya siswa dituntut untuk dapat menangkap hubungan antara pengalaman belajar di sekolah dengan kehidupan dunia nyata

Salah satu metode pembelajaran yang termasuk ke dalam model CTL yang memiliki karakter memberi pengalaman belajar dan bersikap empati adalah metode role model. Metode role model merupakan metode yang dapat menjadi penunjang dalam menumbuhkan sikap empati pada diri siswa. Dengan menampilkan role model baik itu langsung maupun tidak langsung dapat melibatkan siswa untuk merasakan apa yang terjadi pada diri orang lain sehingga dapat memicu tumbuhnya empati. Melalui penerapan metode role model akan dapat dibentuk sikap empati yang lebih baik (Alwasilah, 2007:67).

Berdasarkan pendapat Alwasilah peneliti dapat memahami bahwa metode role model merupakan metode yang dapat merangsang perasaan peserta didik dengan menggunakan model sebagai sumber belajar. Hal tersebut didukung oleh Perry dan Furukaw ( dalam Yanti dkk,2013:2) yang mengatakan bahwa modeling sebagai proses belajar melalui observasi terhadap tingkah laku dari seorang individu atau kelompok, sebagai model, yang berperan sebagai rangsangan bagi pikiran-pikiran, sikap-sikap, atau tingkah laku sebagai bagian dari individu yang lain yang mengobservasi model yang ditampilkan.

Drabman dan Thomas (dalam Taufik, 2012:180) menyatakan bahwa "menemukan bahwa orang-orang (termasuk anak) yang telah memandang model (orang lain) yang murah hati akan menjadi orang yang murah hati dibandingkan orang-orang yang tidak memandang model yang prososial" Berdasarkan pendapat Drabman dan Thomas dapat dipahami bahwa kecakapan-kecakapan sosial tertentu bisa diperoleh dengan mengamati dan mencontoh tingkah laku model-model yang ada.

Berdasarkan kajian peneliti diatas yang meliputi indikasi-indikasi masalah di kelas VII A yang secara umum mengacu pada kurangnya sikap empati 
siswa maka peneliti memilih metode role model sebagai penunjang untuk menumbuhkan sikap empati siswa.

Berdasarkan latar belakang di atas maka fokus permasalahan dalam penelitian ini adalah: "Bagaimana menumbuhkan empati dengan menggunakan metode role model dalam pembelajaran IPS di kelas VII A SMP 44 Bandung?’. Untuk memberikan arah dalam penelitian maka rumusan masalah dituangan kedalam pertanyaan penelitian sebagai berikut:

1. Bagaimana perencanaan pembelajaran untuk menumbuhkan sikap empati siswa dengan menggunakan metode role model dalam pembelajaran IPS?

2. Bagaimana proses pelaksanaan pembelajaran untuk menumbuhkan sikap empati siswa dengan menggunakan metode role model dalam pembelajaran IPS?

3. Bagaimana hasil peningkatan dalam pembelajaran untuk menumbuhkan sikap empati siswa dengan menggunakan metode role model dalam pembelajaran IPS?

4. Bagaimana upaya yang dilakukan oleh guru untuk mengatasi kendala dalam menumbuhkan sikap empati siswa dengan menggunakan metode role model dalam pembelajaran IPS?

\section{B. Metode}

Penelitian tindakan ini dilaksanakan di kelas VII-A SMP Negeri 44 Bandung. Hal ini didasarkan atas hasil observasi awal peneliti, dan juga hasil berdiskusi dengan guru mitra, yang dapat disimpulkan bahwa kelas VII-A memiliki sikap empati yang rendah hal ini ditunjukkan diantaranya pertama, kurangnya tolong-menolong pada saat teman membutuhkan bantuan saat kegiatan belajar mengajar hal ini tampak ketika terjadi ketidaksesuaian antara jumlah buku dan jumlah siswa yang mendapatkan buku pelajaran. Saat itu terlihat sebagian siswa yang memperoleh buku tidak berinisiatif untuk berbagi dengan teman yang tidak kebagian buku pelajaran. Kedua, pada saat kegiatan belajar mengajar peserta didik kurang dalam memperhatikan guru dan teman 
yang sedang berbicaraterkait pelajaran. Ketiga, pada saat kegiatan belajar mengajar siswa terlihat melakukan bullying terhadap teman yang cenderung pendiam di kelas. Keempat, sikap siswa yang membeda-bedakan teman berdasarkan status sosial dan fisik ini terlihat dari posisi tempat duduk dan interaksi siswa. Hal ini terlihat pada bagian barisan depan didominasi oleh siswa yang pintar sedangkan bagian pojok belakang identik dengan siswa pendiam. Kondisi ini menunjukan kurangnya kebersatuan pada siswa kelas VII A. Kelima, sikap ketidak pedulian siswa dengan teman sekelas. Hal ini terlihat ketika ada teman yang tidak hadir sudah lebih empat hari tetapi tidak ada satupun siswa di kelas yang mengetahuinya.

Model yang digunakan oleh peneliti untuk melengkapi proses penelitian ini adalah model Stephen Kemmis dan Robin Mc. Teggart . Menurut Stephen Kemmis dan Robin Mc. Teggart penelitian tindakan dapat dipandang sebagai suatu siklus spiral dari penyusunan perencanaan, pelaksanaan tindakan, pengamatan (observasi), dan refleksi yang selanjutnya mungkin diikuti dengan siklus spiral lainnya dalam Ekawarna (2012,hlm 20).

Penelitian ini menggunakan teknik pengumpulan data dan analisis data. Pada teknik pengumpulan data penelitian ini terdiri dari observasi, wawancara, studi dokumentasi, dan catatan lapangan. Selain itu, penelitian ini menggunakan instrumen yang terdiri dari lembar observasi aktivitas siswa, lembar wawancara siswa sebelum dan sesudah tindakan, lembar wawancara guru, serta catatan lapangan. Kemudian, dilakukan proses analisis data yang terdiri dari aktivitas; (1) Reduksi data merupakan proses berpikir sensitif yang memerlukan kecerdasan dan keluasan dan kedalaman wawasan yang tinggi (Sugiyono, 2011, hlm. 249); (2) Untuk dapat melihat gambaran secara keseluruhan dengan mudah maka harus dibuat dalam berbagai bentuk data menjadi sebuah tabel, bagan, diagram, dan charts; (3) Verifikasi merupakan tinjauan ulang pada catatan-catatan lapangan dengan peninjauan kembali sebagai upaya untuk menguji kebenaran, dan kecocokannya. Adapun bentuk validasi dalam penelitian tindakan kelas ini menggunakan member check yaitu dalam kegiatan ini peneliti menginformasikan penemuan yang diperoleh baik 
kepada guru maupun siswa pada setiap akhir kegiatan pembelajaran, trianggulasi yaitu kegiatan untuk memeriksa kebenaran hipotesis dengan cara membandingkan kebenaran data dengan sumber lain atau hasil peneliti lain, audit trail dilakukan dengan cara mendiskusikan kebenaran data beserta prosedur pengumpulannya dengan guru untuk memperoleh data dengan validasi yang tinggi dan expert opinion yaitu dalam kegiatan ini peneliti mengkonsultasikan temuan-temuannya kepada pembimbing sehingga validasi data temuan yang dapat dipertanggung jawabkan kebenarannya.

Dalam penelitian tindakan kelas menurut Sanjaya (2011, hlm.106), analisis data diarahkan untuk mencari dan menemukan upaya yang dilakukan guru dalam meningkatkan kualitas belajar dan hasil pembelajaran. Data yang terkumpul harus dianalisis terlebih dahulu agar sesuai dengan tujuan penelitian. Adapun data yang diperoleh dalam penelitian ini dianalisis dengan menggunakan analisis data kualitatif. Setelah data terkumpul, peneliti melakukan pengolahan data yang dilakukan secara deskriptif.

Menurut Sugiyono (2010, hlm. 89) analisis data merupakan proses mencari dan menyusun secara sistematis data yang diperoleh dari hasil wawancara, catatan lapangan, observasi, dan dokumentasi, dengan cara mengorganisasikan data kedalam kategori, menjabarkan kedalam unit-unit, melakukan sintesa, menyusun ke dalam pola, memilih mana yang penting dan yang akan dipelajari, dan memuat kesimpulan sehingga mudah dipahami oleh diri sendiri dan orang lain.

\section{Hasil dan Pembahasan}

Data ini diperoleh dari hasil observasi yang dilaksanakan pada siklus pertama, kedua dan ketiga. Adapun indikator-indikator yang terdapat dalam sikap empati siswa adalah sebagai berikut : pertama, perhatian atau emphatic concern kemudian terbagi menjadi sub-indikator yaitu siswa dapat memberikan perhatian terhadap penjelasan guru, menunjukan rasa ingin tahu terkait materi yang dijelaskan guru, siswa dapat menyimak dengan penuh perhatian terkait role model dalam pembelajaran, siswa mencurahkan perhatiannya dalam laporan tertulis terkait role model yang disimak, siswa memberikan laporan secara lisan yang memuat pendapat siswa terkait tokoh 
dan siswa mampu mendengarkan dengan baik teman yang mempresentasikan. Kedua, Pengambilan perspektif (perspective taking) dan terbagi menjadi kedalam subindikator yaitu siswa dapat memahami role model, siswa dapat mengolah pemahaman siswa terkait role model dalam satu perspektif (sudut pandang siswa) dalam hal ini siswa dapat menentuukan konten nilai karakter dalam model tersebut, siswa dapat mengolah hasil perspektif siswa dari role model dengan di asosiasi pada materi IPS, siswa dapat merumuskan mengolah hingga memberi keputusan terhadap sikap empati yang harus siswa lakukan terkait hasil perspektif siswa dan siswa dapat menunjukan sikap empati terkait hasil perolehan perspektif siswa dari role model. Ketiga, Fantasi atau Fantesy dan terbagi menjadi kedalam sub-indikator yaitu menyampaikan perasaan atas suatu kejadian proses yang menyatakan perubahan sikap atau perilaku orang lain, siswa dapat mengidentifikasi tokoh role model secara mendalam (Meminta orang lain untuk menceritakan runut permasalahannya untuk membantu mencari solusi), setelah melakukan proses identifikasi siswa melakukan dialog interaktif yang berkaitan dengan perspektif dari hasil identifikasi, siswa dapat memberikan resolusi terkait role model dan siswa dapat menunjukan sikap empati terhadap role model (menolong). Kelima, Personal distress dan terbagi kedalam subindikator yaitu ikut merasa sedih terhadap penderitaan orang lain dan merasa gusar akibat ketidakadilan yang dirasakan orang lain. Perolehan data dari observasi ini, kemudian dikonversi kedalan rentan skor menggunakan skala interval dan dikonversikan kedalam bentuk nilai, yaitu: Kurang, Cukup, Baik. Berikut ini, merupakan rinciaan skor dari observasi yang telah dilaksanakan.

Tabel 4.1 Presentase Rata-rata Sikap Empati Siswa

\begin{tabular}{|c|l|c|c|c|}
\hline No & \multicolumn{1}{|c|}{ Kelompok } & Siklus 1 & Siklus 2 & Siklus 3 \\
\hline 1. & Satu & 27 & 40 & 48 \\
\hline 2. & Dua & 19 & 38 & 46 \\
\hline 3. & Tiga & 32 & 41 & 48 \\
\hline 4. & Empat & 20 & 35 & 45 \\
\hline 5. & Lima & 26 & 42 & 46 \\
\hline 6. & Enam & 18 & 39 & 43 \\
\hline \multicolumn{2}{|c|}{ Jumlah Skor kelompok } & $\mathbf{1 4 2}$ & $\mathbf{2 3 5}$ & $\mathbf{2 7 6}$ \\
\hline
\end{tabular}




\begin{tabular}{|c|c|c|c|}
\hline Jumlah skor makasimal & 324 & 324 & 324 \\
\hline Rata-rata & $\mathbf{4 3 . 8 \%}$ & $\mathbf{7 2 . 5 \%}$ & $\mathbf{8 5} \%$ \\
\hline
\end{tabular}

Perhitungan rata-rata (presentase) : Jumlah skor kelompok X 100

Jumlah maksimal

Konversi Rata-Rata (Presentase)

\begin{tabular}{|l|c|}
\hline \multicolumn{1}{|c|}{ Nilai } & Skor Presentase \\
\hline Kurang & $0-33,3 \%$ \\
\hline Cukup & $33,4 \%-66,6 \%$ \\
\hline Baik & $66,7 \%-100 \%$ \\
\hline
\end{tabular}

Berdasarkan hasil dari tabel 4.6 Dapat dilihat perkembangan sikap empati siswa dari hasil perolehan skor pada setiap pelaksanaan siklusnya.Perkembangan terlihat sudah baik, dimana setiap anggota kelompok mampu menumbuhkan sikap empati selama penerapan metode role model dalam pembelajaran IPS. Berikut diagram skor yang didapatkan dari setiap kelompok dalam menumbuhkan sikap empati siswa melalui penerapan metode role model dalam pembelajaran IPS.

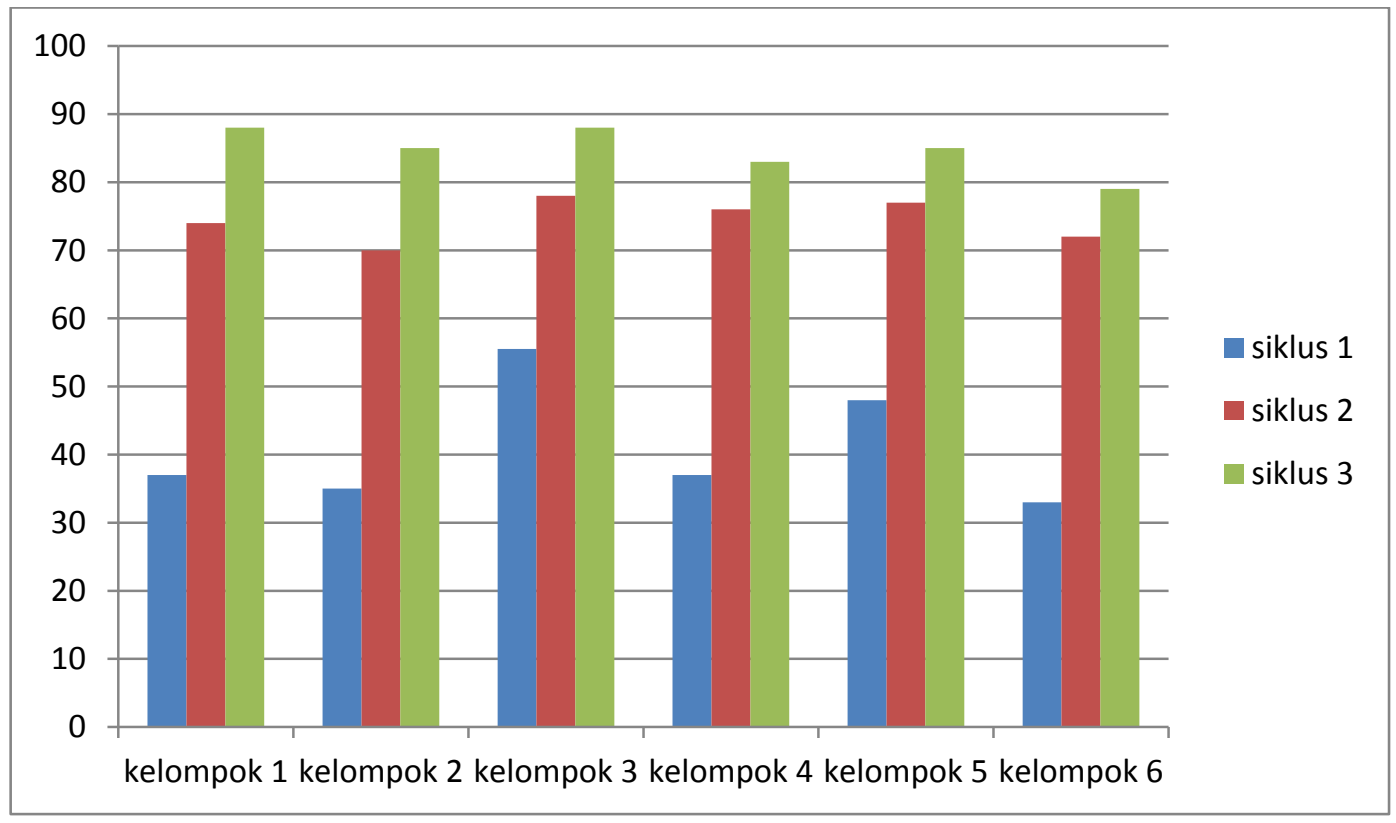

Gambar 4.1 Diagram Skor Peningkatan Sikap Empati Siswa

Diolah oleh peneliti tahun 2015 
Dari data diatas dapat diketahui bahwa sikap empati siswa melalui penggunaan metode role model siswa mengalami peningkatan dengan baik. Berdasarkan hasil dari siklus pertama rata-rata presentase yang didapatkan mencapai $48,8 \%$ uang masuk pada kategori cukup hasil ini masih kurang untuk indikasi ketercapaian sikap empati, hal ini diasumsikan karena masih banyak siswa yang mampu memenuhi kriteria sikap empati. Selanjutnya hasil sikap empati siswa pada siklus kedua mencai rata-rata $72,5 \%$ yang termasuk pada kategori baik. Pada siklus kedua ini mengalami peningkatan sebesar $23.7 \%$ dari siklus sebelumnya. Hal ini diasumsikan siswa sudah memenuhi kriteria sikap empati. Sedangkan pada siklus ketiga perolehan nilai sikap empati siswa adalah $85 \%$, pada siklus ketiga ini sikap empati siswa mengalami peningkatan hanya 12,5\% saja. Hal ini diasumsikan bahwa pada siklus ketiga ini sudah stabil dan berada pada titik kenuh siswa.

Berdasarkan presentasi tersebut agar lebih terlihat jelas mengenai perubahan sikap empati siswa melalui metode role model dalam pembelajaran IPS, dapat digambarkan pada diagram dibawah ini :

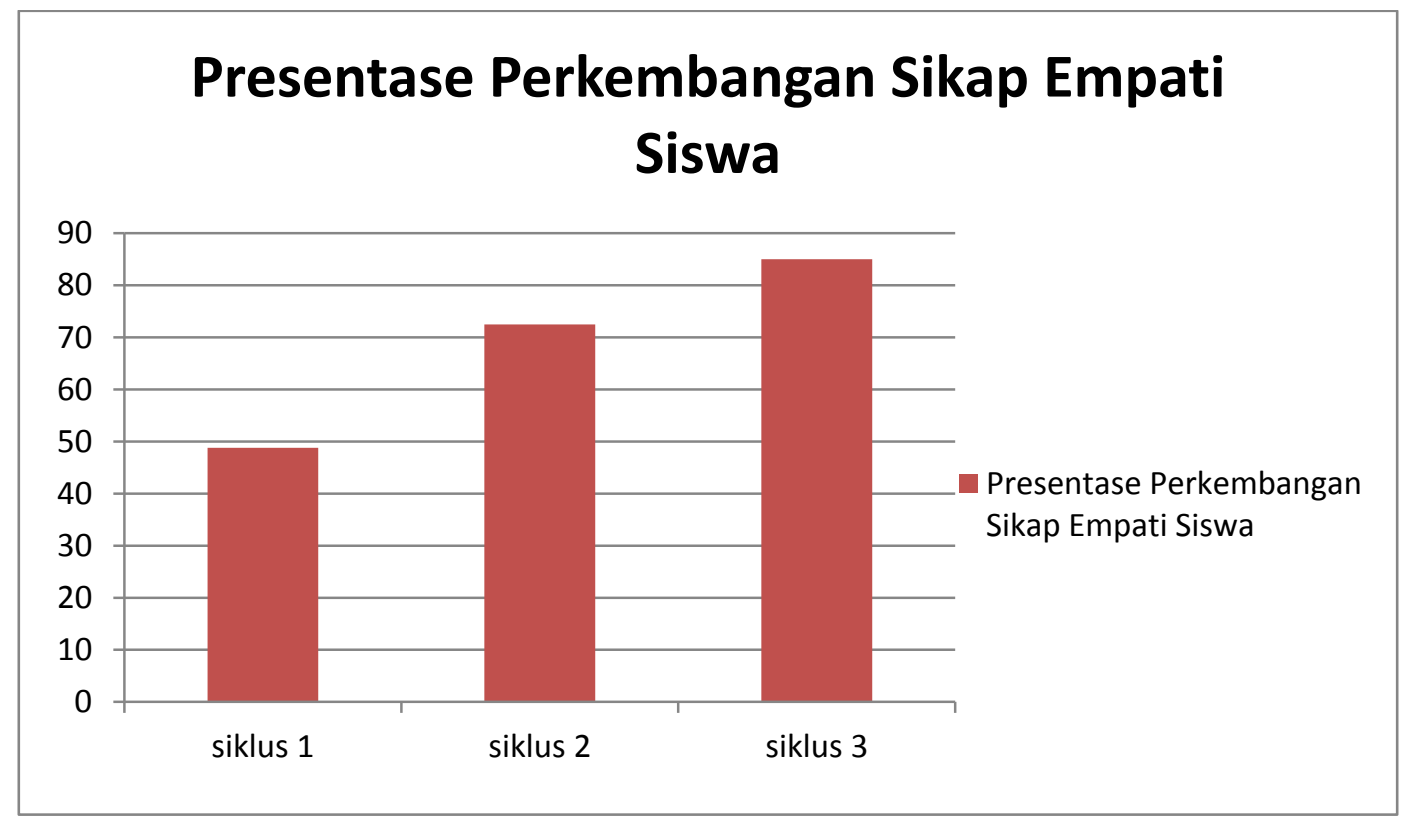

Gambar 4.2 Diagram Presentase Peningkatan Sikap Empati Siswa

Diolah oleh penulis tahun 2015

Berdasarkan data yang diperoleh selama penelitian, dapat dikatakan bahwa sikap empati siswa kelas VII A SMPN 44 Bandung dapat meningkat melalui penerapan metode role model, peningkatan ini terlihat pada siklus pertama sampai siklus ketiga. 
Pada siklus pertama siswa belum begitu terlihat antusias dalam mengikuti pembelajaran dengan menggunakan metode role model, ini karena sosok role model yang ditampilkan tidak langsung didatangkan ke dalam kelas melainkan melalui tayangan video dan siswa masih mengalami kebingungan untuk mengaitkan antara role model dengan materi IPS, siswa masih terlihat tidak disiplin dan belum terlihat adanya sikap empati dan siswa msih terlihat tidak fokus terhadap model yang ditampilkan.

Pada siklus kedua, perkembangan sikap empati siswa melalui metode role model mengalami peningkatan, hal ini dapat dilihat ketika siswa sudah mampu untuk fokus kepada sosok role model yang didatangkan yaitu pak ade sebagai petugas kebersihan, kemudian siswa sudah mampu untuk menunjukan sikap empatinya saat pembelajaran berlangsung dan sudah cukup dapat mengasosiasikan model yang didatangkan dengan metari IPS. Kemudian pada siklus ketiga, perkembangan sikap empati siswa melalui metode role model mengalami oeningkatan progresif dan sudah dalam kategori baik.

\section{Kesimpulan}

Berdasarkan hasil penelitian tindakan kelas yang telah dilaksanakan di kelas VII A SMP Negeri 44 Bandung dalam menumbuhkan sikap empati siswa dengan menggunakan metode role model dalam pembelajaran IPS dapat ditarik kesimpulan sebagai berikut: Pertama, Perencanaan yang dilakukan guru dalam menumbuhkan sikap empati siswa dengan menggunakan metode role model dalam pembelajara IPS di kelas VII-A SMPN 44 Bandung, diawali dengan langkah guru melakukan observasi. Hasil observasi menunjukan pertama, kurangnya tolong menolong saat teman membutuhkan bantuan saat kegiatan belajar mengajar.Kedua, pada saat kegiatan belajar mengajar peserta didik kurang memperhatikan guru dan teman yang sedang menjelaskan terkait dengan materi pembelajaran. Ketiga, pada saat kegiatan belajar mengajar beberapa siswa terlohat melakukan bullying terhadap teman yang cenderung pendiam di kelas. Keempat, terlhat adanya sikap membeda-bedakanteman berdasarkan status sosial dan fisik. Kondisi tersebut menunjukan adanya fenomena sikap membeda-bedakan pada siswa kelas VII-A. Kelima, sikap ketidak pedulian siswa dengan teman sekelas. Hasil identifikasi pada saat observasi kemudian dijadikan dasar 
merumuskan fokus penelitian. Tahap tersebut kemudian dilanjutkan dengan tahap diskusi bersama guru mitra untuk menyusun Rencana Pelaksanaan Pembelajaran (RPP) yang memacu siswa untuk menumbuhkan sikap empati. Selanjutnya, peneliti membuat instrumen yang dijadikan sebagai alat pengumpulan data hasil penelitian, yaitu lembar observasi siswa, lembar wawancara, catatan lapangan, dan dokumentasi. Selain itu, guru menggunakan lembar observasi kegiatan siswa.

Kedua, Penerapan metode role model telah dapat menumbuhkan sikap empati siswa dalam pembelajara IPS melalui tiga siklus. Peningkatan tiap siklus cukup signifikan dan dalam setiap siklusnya terdiri dari satu tindakan. Pada pelaksanaan siklus pertama, peneliti dengan guru mitra menemukan bahwa sikap empati siswa, belum mencapai kategori yang cukup signifikan. Oleh karena itu peneliti dan guru mitra merencanakan melakukan siklus kedua. Pada siklus kedua peneliti melakukan pembelajaran menggunkan metode yang sama yaitu metode role model tetapi dengan materi dan model yang berbeda yaitu dengan mendatangkan langsung model kedalam kelas yang bekerja sebagai petugas kebersihan. Pada siklus ini peneliti dan guru mitra menemukan bahwa ketercapaian penilaian sikap empati mengalami peningkatan yaitu memperoleh nilai dengan kategori baik secara signifikan. Setelah dilakukan dua kali siklus, untuk melihat konsistensi hasil dari sikap empati siswa, disepakati dilakukan siklus ketiga. Siklus ketiga membuktikan secara terstruktur bahwa sikap empati siswa mengalami peningkatan. Dengan kecenderungan yang konsisten, peningkatan sikap empati siswa tersebut, peneliti dan guru mitra memutuskan untuk mengakhiri penelitian tindakan kelas.

Ketiga, Kendala yang dihadapi oleh guru dalam menerapkan metode role model dalam pembelajaran IPS di kelas VII-A adalah berkaitan dengan aspek pelaksanaaan. Namun demikian untuk aspek pelaksanaan khususnya dalam megkondisikan kelas dan mengalokasikan waktu, guru melakukan pemecahan masalah dengan selalu meningkatkan kemampuan mengalokasikan waktu dalam RPP dengan pelaksanaan dikelas.kemampuan guru dalam 
mengkondisikan kelas harus ditingkatkan lagi dengan mempertegas diri sehingga setiap kendala yang dihadapi guru dalam pembeljaran dapat terselesikan dengan baik.

Keempat, Metode role model dalam tiga siklus mampu membangun sikap empati siswa. Pada siklus pertama, mulai menunjukan peningkatan walaupun belum terlihat dalam observasi secara nyata, tetapi pada siklus kedua terlihat dengan jelas, dan siklus ketika sangat jelas. Peningkatan siswa diperoleh dari gambaran pencapaian indikator sikap empati siswa pada awalnya masuk kedalam klasifikasi cukup. Meningkat naik pada siklus kedua menjadi klasifikasi baik. Dan pada siklus ketiga, siswa memiliki sikap empati mencapai klasifikasi sangat baik. Dampak lain dari menggunakan metode role model mampu meningkatkan minat belajat siswa terlihat dari hasil wawancaraketika observasi pada umumnya siswa menyatakan menyuka metode tersebut. Karena siswa dapat berinteraksi langsung dengan narasumbersehingga dalam pelaksanaan penelitian dari siklus satu hingga siklus ketiga menunjukan indikator bahwa siswa antusias dalam pembelajaran IPS. 
